\title{
Eozinofilų ịtaka bronchų lygiųjų raumenų remodeliacijai sergant astma
}

\author{
ANDRIUS JANUŠKEVIČIUS, IEVA JANULAITYTĖ, VIRGINIJA KALINAUSKAITĖ-ŽUKAUSKE், \\ KĘSTUTIS MALAKAUSKAS \\ LSMU MA Pulmonologijos klinika
}

\begin{abstract}
LSMU MA Pulmonologijos kinikos mokslininku grupé: prof. R. Sakalauskas, doktorantai A. Januškevičius, Ieva Janulaitytè, V. Kalinauskaitè-Žukauskè, dr. D. Hoppenot ir dr. S. Vaitkiené, vadovaujama prof. K. Malakausko ir bendradarbiaudama su Nyderlandų Groningeno universiteto Molekulinés farmakologijos departamentu (atstovas doc. R. Gosens), nuo 2014 m. kovo iki 2016 gruodžio vykdé Lietuvos mokslo tarybos finansuotą projektą „Eozinofilų įtaka bronchų lygiujų raumenų remodeliacijai sergant astma“ (finansavimo sutarties Nr. MIP-010/2014).
\end{abstract}

Astma yra lètinė uždegiminė kvėpavimo takų liga, kuriai būdinga išnykstanti bronchų obstrukcija ir bronchų hiperreaktyvumas, padidèjęs aktyvuotų uždegiminių ląstelių ir uždegiminių mediatorių kiekis. Nors astmos etiologija pakankamai gerai ištirta, ligos patogenezè, ịskaitant molekulinius ligos išsivystymo mechanizmus, iki šiol nepakankamai ištirta. Labiausiai pastebimas ir svarbiausias kvèpavimo taku struktūrinis pokytis yra bronchų lygiųjų raumenų masès padidèjimas ir bronchų spindžio susiaurèjimas. Šiuos pokyčius lemia suintensyvèjusi bronchų lygiujuc raumenų ląstelių proliferacija, padidejjęs ląstelių dydis bei gausesnè tarpląstelinio matrikso baltymų gamyba [1]. Eozinofilai yra pagrindinès uždegiminès ląstelès, ittrauktos $\mathfrak{i}$ astmos patogenezę bei prisidedančios prie bronchų lygiųų raumenų remodeliacijos vystymosi. Eozinofilai - tai cirkuliuojantys granuliocitai, kurie gali migruoti ị kvèpavimo takus, reaguodami ị imunologinius ir uždegiminiųs dirgiklius [2]. Veikiant interleukinui-5 bei CCL11 ir CCL5 citokinams, eozinofilai migruoja $\mathfrak{i}$ kvejpavimo takus, prisitvirtina prie aktyvuotų endotelio ląstelių ir po diapedezès proceso gali kontaktuoti su kvépavimo takų membranoje esančiomis struktūrinėmis ląstelèmis (bronchų lygiųjų raumenų ląstelèmis, plaučių fibroblastais, epitelio ląstelèmis) [3]. Eozinofilai veikia šias ląsteles dvejopai: netiesiogiai, per išskiriamus ịvairius citokinus, chemokinus, augimo faktorius arba reaktyviąsias deguonies formas; tiesiogiai (adhezijos būdu), t. y. po jų prisitvirtinimo prie struktūrinių ląstelių adhezijos molekulių per savo paviršinius integrinus [4]. Toks eozinofilu poveikis gali prisidèti prie sutrikusios ląstelių proliferacijos, diferenciacijos, tarpląstelio matrikso gamybos ir molekulinių signalinių kelių aktyvacijos taip prisidedant prie bronchų lygiųjų raumenų remodeliacijos vystymosi (1 pav.).

Wingless, integrazès-1 (Wnt) signalinis kelias re- guliuoja įvairius organų vystymosi procesus, todèl sutrikusi jo aktyvacija sąlygoja galimą ịvairių ligų išsivystymą [5]. Kumawat ir kt. (2013) pirmą kartą nustate nekanoninio Wnt signalinio kelio, aktyvuojamo Wnt5 a ligando, ir transformuojančio augimo faktoriaus- $\beta_{1}$ (TGF- $\beta_{1}$ ) reikšmę bronchų lygiųjų raumenų ląstelių savybèms sergant plaučių ligomis [6]. Šio tyrimo metu buvo norima išsiaiškinti, ar eozinofilai turi įtakos Wnt ligandų raiškai, kuris, kartu su TGF- $\beta_{1}$ galètų sukelti bronchų lygiųjų raumenų ląstelių aktyvumo pokyčius, ìskaitant jų proliferaciją, tarpląstelinio matrikso baltymų gamybą bei ịvairių citokinų išskyrimą (1 pav.).

\section{TYRIMO TIKSLAS}

Ištirti eozinofilų ịtaką bronchų lygiųjų raumenų remodeliacijai sergant astma.

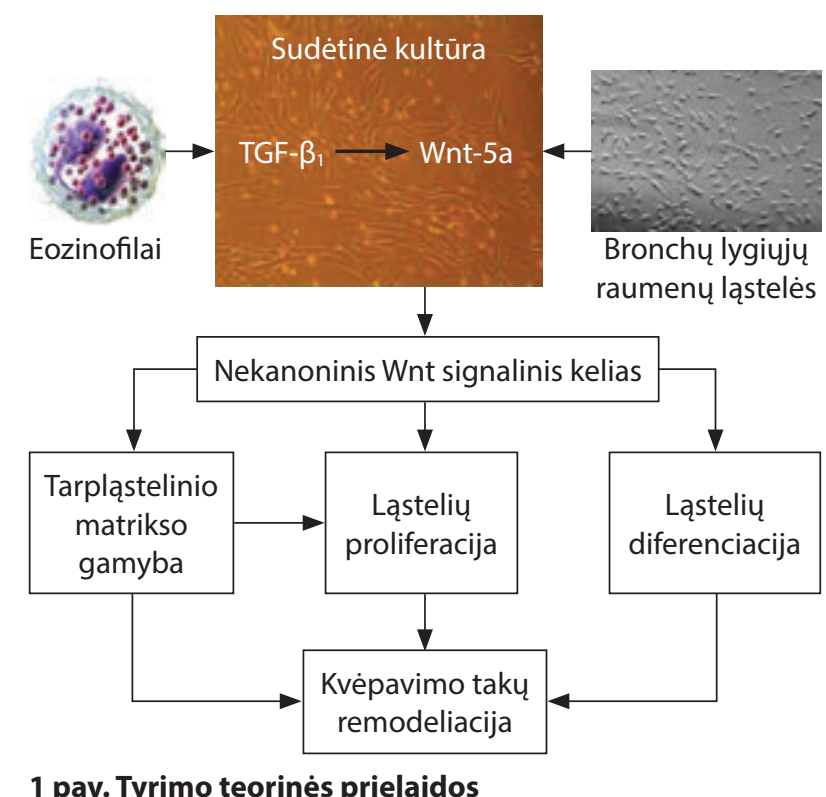




\section{Moksliniai darbai}

\section{TYRIMO UŽDAVINIAI}

- İvertinti eozinofilų poveikị bronchų lygiưjų raumenų ląstelėms, nustatant TGF- $\beta_{1}$ ir Wnt-5a) gamybą sergant astma.

- Ivvertinti eozinofilų integrinų įtaką bronchų lygiųjų raumenų ląstelių proliferacijai sergant astma.

- Ištirti alergeno poveikị eozinofilų integrinų sąveikai su bronchų lygiujų raumenų ląstelemis ir Wnt-5a baltymo gamybai.

\section{TIRIAMŲJŲ KONTINGENTAS}

Moksliniame tyrime dalyvavo 19-49 metų nerūkantys asmenys, kurie tirti ir gydyti LSMUL KK Pulmonologijos klinikoje. Iš viso ị tyrimą ịtraukti 39 asmenys: 22 sergantieji astma ir 17 sveiki asmenys (kontroline grupè). Kiekvienas iš tiriamųju pasirašè informuoto asmens sutikimo formą bei atitiko ịtraukimo ir neịtraukimo kriterijus. Beveik visiems astma sergantiesiems pacientams nustatytas didesnis eozinofilų kiekis periferiniame kraujyje bei padidėjęs eozinofilų skaičius indukuotuose skrepliuose. Kiekvienam tiriamajam atliktas inhaliacinis bronchų provokacinis mèginys su namų dulkių erkių Dermatophagoides pteronyssinus alergenu didejjančiomis koncentracijomis $(0,1,1,0$, 10,0 ir 33,3 IR/ml). Mèginys laikomas teigiamu, kai FEV1 nuo pradinès vertès sumažèja ne mažiau 20 proc. Siekiant igyvendinti tyrime iškeltus uždavinius, buvo sudaromos individualios tiriamuju kraujo eozinofilu ir linijinių bronchų lygiụjų raumenų ląstelių sudètinès kultūros imituojant in vivo vykstančią šių dviejų ląstelių tipų tarpusavio sąveiką.

\section{TYRIMO EIGA}

Atvykti į Lietuvos sveikatos mokslų universiteto Pulmonologijos kliniką tiriamieji buvo kviečiami du kartus. Atrankos vizito metu (pirmas vizitas) patikrinti itraukimo, neịtraukimo kriterijai, atliktas plaučių funkcijos tyrimas, bronchų provokacinis mėginys su metacholinu ir alerginiai odos dūrio méginiai. Antro vizito metu atlikta spirometrija prieš ir po bronchų provokacinio méginio su specifiniu alergenu $D$. pteronyssinus, paimta periferinio kraujo, indikuoti skrepliai, išskiriami eozinofilai ir sudaromos sudètinès ląstelių kultūros su bronchų lygiưjų raumenų ląstelèmis.

Po sudètinių kultūrų sudarymo vertinama eozinofilų adhezija prie bronchų lygiưjų raumenų ląstelių laiko etapais (nuo 30 iki $240 \mathrm{~min}$.) matuojant eozinofilu peroksidazès (EPO) aktyvumą spektrofotometriniu metodu, naudojant specifinị EPO substratą. Bronchų lygiụjų raumenų ląstelių proliferacija po sąveikos su eozinofilais matuota vertinant AlamarBlue ${ }^{\oplus}$ reagento redukciją, priklausančią nuo ląstelių metabolinio aktyvumo praejus 48 ir 72 val. nuo sudètinès kultūros sudarymo. Renkami méginiai augimo faktorių, už eozinofilų adheziją prie bronchų lygiụjų raumenų

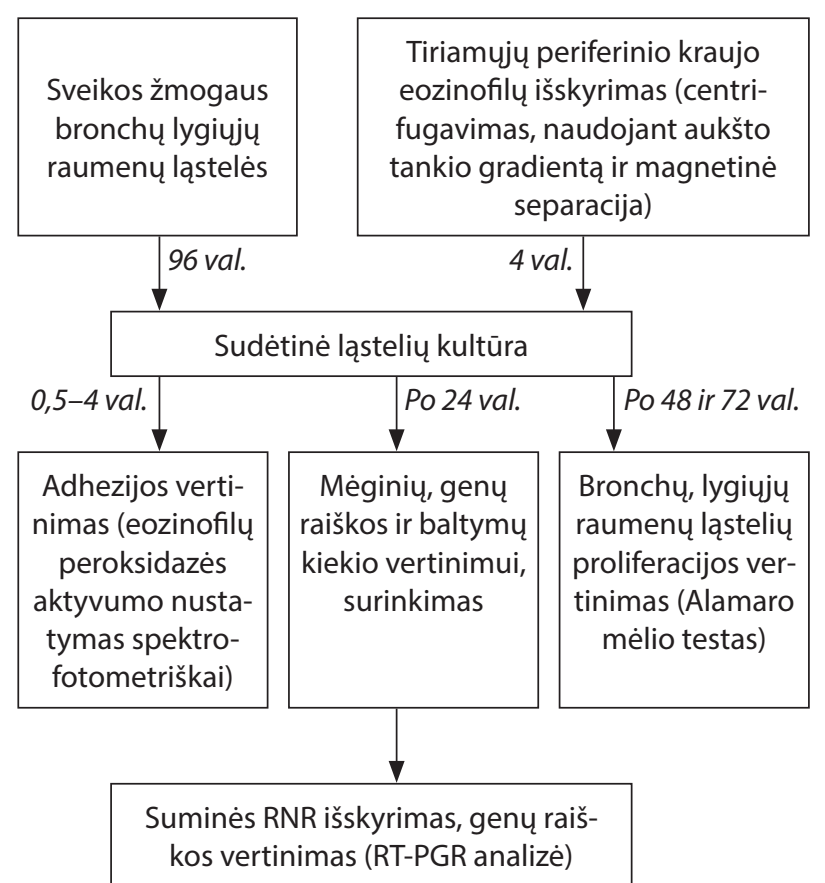

2 pav. Darbo planas ir tyrimo metodika

ląstelių atsakingų paviršiaus integrinų, tarpląstelinio matrikso baltymų įvertinimui bei genų raiškos analizei. WNT-5A ir TGF- $\beta 1$, paviršiaus integrinų, kolageno ir fibronektino genų raiškos vertintos realaus laiko polimerazinès grandininès reakcijos (RL-PGR) metodu (2 pav.).

\section{PAGRINDINIAI REZULTATAI}

\section{Eozinofilų integrinų raiška}

Nustatėme, kad iš astma sergančių asmenų eozinofilų išskirtoje mRNR integrinų subvienetų raiška buvo padidejjusi atitinkamai: $\alpha 4$ raiška $-3,7 \pm 1,0$ karto, $\alpha \mathrm{M}$ raiška $-4,6 \pm 1,4, \beta_{1}$ raiška $-4,1 \pm 1,1, \beta_{2}$ raiška $-16,8 \pm 4,9$ karto lyginant su sveikų asmenų eozinofilais. Taip pat nustateme, kad didesnis eozinofilų integrinų $\alpha_{4}, \alpha \mathrm{M}$, $\beta_{1}$ ir $\beta_{2}$ mRNR kiekis lèmé padidèjusią jų adheziją prie bronchų lygiụjų raumenų ląstelių. Kiekvienam tiriamajam buvo sudaryta sudètinè kultūra su eozinofilais, išskirtais iš asmens periferinio kraujo, ir bronchų lygiųjų raumenų ląstelèmis. Po 24 val. inkubacinio laikotarpio pastebėjome, kad sergančiųjų astma eozinofiluose buvo $6,0 \pm 1,8$ karto didesnis integrino $\alpha_{4}$ mRNR kiekis, lyginant su eozinofilais, kurie nebuvo inkubuojami sudètinèje kultūroje $(\mathrm{p}<0,05)$. Kitų integrinų raiškai, tiek sveikų, tiek sergančiụjų astma grupèse sudètinès kultūros sudarymas ittakos neturejo.

\section{Eozinofily̨ adhezija}

Eozinofilų adhezija prie bronchų lygiụjų raumenų ląstelių buvo reikšmingai padidejjusi astma sergančiųjų grupejje visais vertintais laiko etapais (nuo $30 \mathrm{iki}$ $240 \mathrm{~min}$.) lyginant su sveikų asmenų grupès eozinofilų 


\section{Moksliniai darbai}

adhezijos reikšmėmis. Nustatėme, kad integrinų blokavimas su RGDS peptidu procentine dalimi reikšmingai sumažino eozinofilų adheziją abiejose tiriamųjų grupėse. Kontrolinès grupès adhezijos reikšmė sumažèjo vidutiniškai 9,54 $\pm 0,71$ proc., o integrinų blokavimas astma sergančiųjų grupèje adheziją sumažino vidutiniškai $13,53 \pm 2,70$ proc. Taip pat nustatème, kad inhaliacinis bronchų provokacinis mėginys su specifiniu alergenu lèmé padidejjusią astma sergančiųjų eozinofilų adheziją.

\section{TGF- $\beta_{1}$ kiekybiniai matavimai}

Nustatème didesnę TGF- $\beta_{1}$ geno raišką sergančiųjų astma eoinofiluose lyginant su sveikų asmenų. Inhaliacinis bronchų provokacinis mėginys su specifiniu alergenu dar labiau padidino skirtumus tarp tiriamuju grupių. Taip pat nustateme, kad eozinofilai didina TGF- $\beta_{1}$ geno raišką bronchų lygiųjų raumenų ląstelèse abiejų grupių sudètinèse kultūrose, tačiau astma sergančiųjų grupèje padidejjimas buvo reikšmingai didesnis. Eozinofilų integrinų blokavimas sumažino jų ịtaka bronchų lygiųjų raumenų ląstelèms abiejų tiriamųjų grupèse. Šie duomenys buvo patvirtinti baltymų koncentracijos tyrimais iš surinkto sudetinès kultūros supernatanto, kurie atitiko gautus genų raiškos rezultatus

\section{Eozinofilai skatina WNT-5a ir tarpląstelinio matrikso baltymų gamybą}

Praejjus 24 val. po sudètinès kultūros sudarymo su sergančiųjų astma eozinofilais, nustatyta, kad WNT-5a geno raiška bronchų lygiụjų raumenų ląstelèse padidè-

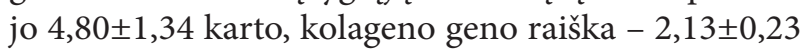
karto, lyginant su bronchų lygiųjų raumenų ląstelèmis be sąveikos su eozinofilais. Nerasta reikšmingų genų raiškos pokyčių bronchų lygiųjų raumenų ląstelèse po inkubacijos su eozinofilais išskirtais iš sveikų asmenų. Taip pat nustatyta, kad eozinofilai, išskirti tiek iš astma sergančiųjų, tiek iš sveikų asmenų, reikšmingai padidino fibronektino geno raišką bronchų lygiųjų raumenų ląstelèse lyginant su kontrolinėmis bronchų lygiưjų raumenų ląstelèmis, be sąveikos su eozinofilais, atitinkamai $1,71 \pm 0,25$ ir 1,73 $\pm 0,20$ karto. Sumažejusi eozinofilų adhezija prie bronchų lygiųjų raumenų ląstelių arba tarpląstelinio matrikso baltymų paviršiaus, blokuojant RGDS peptidu, turèjo reikšmingą WNT-5a, fibronektino ir kolageno genų raiškos slopinamąji poveiki.

\section{Eozinofilų sukelta bronchų lygiujjų raumenų ląstelių proliferacija}

Sergančiųjų astma eozinofilai labiau skatino bronchų lygiųjų raumenų ląstelių proliferaciją, lyginant su sveikų asmenų eozinofilais, atitinkamai - 21 ir 5 proc. Po bronchų lygiujuc raumenų ląstelių inkubacijos su eozinofilais, kurių integrinai buvo blokuoti, šių ląste- lių proliferacija sumažejo nuo 21 iki 10,5 proc. ribos astma sergančiųjų grupejje, o sveikų asmenų grupejje proliferacija sumažejo nuo 5 iki 2,15 proc.

\section{IŠVADOS}

Gavus eksperimentinių tyrimų rezultatus, padarytos tokios išvados:

- Dèl intensyvesnès paviršiaus integrinų raiškos eozinofilai pasižymi stabilesne ir tvirtesne adhezija prie bronchų lygiųjų raumenų ląstelių sergant astma.

- Sergant astma eozinofilai skatina Wnt-5a ir TGF- $\beta_{1}$ genų raišką bronchų lygiųjų raumenų ląstelèse ir sąlygoja padidèjusią fibronektino ir kolageno gamybą.

- Sergančiųjų astma eozinofilai labiau skatina bronchų lygiujuc raumenų ląstelių proliferaciją, lyginant su sveikų asmenų eozinofilais, patikimai prisidedami prie bronchų lygiųjų raumenų remodeliacijos vystymosi.

- Eozinofilų integrinų blokavimas patikimai slopina juc adhezija bei ittaką Wnt-5a, TGF- $\beta_{1}$, tarpląstelinio matrikso baltymų genų raiškai bei bronchų lygiưjų raumenų ląstelių proliferacijai sergant astma.

- Inhaliacinis bronchų provokacinis mėginys su specifiniu alergenu skatino eozinofilų aktyvumą, ìskaitant jų adhezija bei ịtaką bronchų lygiųjų raumenų ląstelių proliferacijai.

\section{PRAKTINÉ TYRIMO REIKŠMÉ}

Šio mokslinio tyrimo rezultatai suteikia naujos informacijos apie astmos patogenezę. Nustatėme, kad:

1. Eozinofilų poveikis bronchų lygiųjų raumenų ląstelèms, sergant astma yra svarbi tiesioginè jų adhezija per integrinų-ligando sąveiką.

2. Padidejusi tarpląstelinio matrikso pgamyba sergant astma priklauso nuo eozinofilų aktyvuojamo TGF- $\beta_{1}$-Wnt signalinių kelių tarpusavio sąveikos.

3. Bronchų lygiųjų raumenų remodeliacija gali būti iš dalies kontroliuojama blokuojant eozinofilų integrinus ir taip slopinant jų adheziją prie bronchų lygiụjų raumenų ląstelių bei nuo integrinų priklausomą signalo perdavimą.

\section{REZULTATU SKLAIDA}

Remiantis gautais rezultatais, publikuoti du straipsniai užsienyje leidžiamuose periodiniuose mokslo leidiniuose, turinčiuose cituojamumo rodikli (Impact factor) Clarivate Analytics (buvusi Thomson Reuters) Web of Science duomenų bazèje:

- Januskevicius A, Gosens R, Sakalauskas R, Vaitkiene S, Janulaityte I, Halayko AJ, Hoppenot D, Malakauskas K. Suppression of Eosinophil Integrins Prevents Remodeling of Airway Smooth 


\section{Moksliniai darbai}

Muscle in Asthma. Frontiers in Physiology. 2016; 7:680.

- Januskevicius A, Vaitkiene S, Gosens R, Janulaityte I, Hoppenot D, Sakalauskas R, Malakauskas K. Eosinophils enhance WNT-5a and TGF- $\beta_{1}$ genes expression in airway smooth muscle cells and promote their proliferation by increased extracellular matrix proteins production in asthma. BMC pulmonary medicine. 2016 Jun 13;16(1):94. Taip pat pristatyta 11 mokslinių tezių - trys Lietuvos ir aštuonios užsienyje vykusiose tarptautinėse konferencijose, publikuoti trys mokslo populiarinimo darbai tyrimo tematika. Tyrimo metu gauti rezultatai buvo panaudoti dviem bakalauro ir dviem magistro baigiamiesiems darbams.

\section{LITERATŪRA}

1. Araujo BB, Dolhnikoff M, Silva LF, Elliot J, Lindeman JH, Ferreira DS, et al. Extracellular matrix components and regulators in the airway smooth muscle in asthma. Eur Respir J. 2008; 32(1):61-9.

2. Possa SS, Leick EA, Prado CM, Martins MA, Tibério IF. Eosinophilic inflammation in allergic asthma. Front Pharmacol. 2013; 4:46.

3. Doeing DC, Solway J. Airway smooth muscle in the pathophysiology and treatment of asthma. J Appl Physiol. 2013; 114(7):834-43.

4. Barthel SR, Johansson MW, McNamee DM, Mosher DF. Roles of integrin activation in eosinophil function and the eosinophilic inflammation of asthma. J Leukoc Biol. 2008; 83(1):1-12.

5. Sharma S, Tantisira K, Carey V, Murphy AJ, Lasky-Su J, Celedón JC, et al. A role for Wnt signaling genes in the pathogenesis of impaired lung function in asthma. Am J Respir Crit Care Med. 2010; 181(4):328-36.

6. Kumawat $\mathrm{K}$, Menzen MH, Bos IS, Baarsma HA, Borger P, Roth M, et al. Noncanonical WNT-5A signaling regulates TGF-beta-induced extracellular matrix production by airway smooth muscle cells. FASEB J. 2013; 27(4):1631-43. 